\title{
Entre espelhos fantásticos: ficcionalização, religião e literatura*
}

\author{
Marcio Cappelli Aló Lopes** \\ Paulo Nogueira***
}

\section{Resumo}

O presente artigo tem como objetivo precípuo mostrar, de maneira interdisciplinar, como a teoria da literatura pode contribuir para o campo das Linguagens da Religião. De maneira mais específica pretendemos evidenciar de que maneira a noção de ficcionalização (mais ou menos consciente) é um procedimento compartilhado pela religião e pela literatura, tendo inclusive bases antropológicas, se constituindo em uma forma fundamental de conhecimento. No entanto, ainda que consideremos tais afinidades, não ignoramos as diferenças existentes entre religião e literatura. Portanto, no percurso argumentativo, propomos a reflexão através dos seguintes passos: 1) ficcionalização, conhecimento e realidade - onde buscaremos mostrar a ficção na realidade (i.e. a ficcionalização como elemento básico da comunicação, do conhecimento e das ações) e a realidade na ficção (i.e. os mecanismos do procedimento ficcional); 2) ficcionalização e religião - em que o foco será indicar o que há de ficcionalização na religião e o que há de religioso na ficção; e, por fim, 3) aventar algumas interpelações da

* Este artigo é fruto de reflexões que se deram no contexto de um curso ministrado pelos autores no ano de 2019, na disciplina obrigatória da área de concentração Linguagens da Religião, do PPG em Ciências da Religião da UMESP, intitulada "Linguagens da religião: questões epistemológicas". Na ocasião pudemos compartilhar nossas perspectivas sobre o papel da ficcionalidade da narrativa literária e religiosa, a partir de diversos autores dos estudos literários, discursivos e semióticos. Também queremos fazer menção à participação do Prof. Dr. Vitor Chaves de Souza nesses debates e em algumas das sessões do curso.

** Universidade Metodista de São Paulo - PPG em Ciências da Religião. Doutor em Teologia (Puc-Rio); Professor no PPG em Ciências da Religião da Universidade Metodista de São Paulo.marcio.lopes@metodista.br .

*** PUC Campinas. Doutor em Teologia pela Universidade de Heidelberg (Ruprecht-Karls), fez estudos pós-doutorais em História no NEE/Unicamp. É professor pesquisador da Pós-graduação em Ciências da Religião da Pontifícia Universidade Católica de Campinas. pasn777@gmail.com . 
Paulo Nogueira

ficção literária à religião - quando, então, pretendemos colocar a questão do horizonte humanístico. Dessa forma, esperamos contribuir para um renovado olhar em relação aos textos religiosos e sua recepção na literatura.

Palavras-chave: ficcionalização; religião; literatura; linguagens da religião, teopoética.

\title{
Between fantastic mirrors: fictionalization, religion and literature
}

\begin{abstract}
The main objective of this article is to show, in an interdisciplinary way, how the literary theory can contribute to the field of Languages of Religion. More specifically, we intend to show how the notion of fictionalization (more or less conscious) is a procedure shared by religion and literature, including anthropological bases, constituting a fundamental form of knowledge. However, even though we consider such affinities, we do not ignore the differences between religion and literature. Therefore, in the argumentative way, we propose a reflection through the following steps: 1) fictionalization, knowledge and reality - where we will seek to show fiction in reality (fictionalization as a basic element of communication, knowledge and actions) and reality in fiction (the mechanisms of the fictional procedure); 2) fictionalization and religion - in which the focus will be to indicate what is fictionalized in religion and what is religious in fiction; and, finally, 3) we pretend to suggest some interpellations from literary fiction to religion - when, then, we intend to raise the question of the humanistic horizon. In this way, we hope to contribute to a renewal look for the religious texts and their reception in literature.
\end{abstract}

Keywords: fictionalization; religion; literature; languages of religion; theopoetics.

\section{Entre espejos fantásticos: ficcionalización, religion y literatura}

\section{Resumen}

El objetivo principal de este artículo es mostrar, de forma interdisciplinar, cómo la teoría de la literatura puede contribuir al campo de los lenguajes de religión. Más concretamente, pretendemos mostrar cómo la noción de ficcionalización (más o menos consciente) es un procedimiento compartido por la religión y la literatura, que incluye bases antropológicas, constituyendo una forma fundamental de conocimiento. Sin embargo, aunque consideramos tales afinidades, no ignoramos las diferencias existentes entre religión y literatura. Por tanto, en la vía argumentativa, proponemos la reflexión a través de los siguientes pasos: 1) ficcionalización, conocimiento y realidad - donde buscaremos mostrar la ficción en la realidad (es decir, la ficcionalización como elemento básico de la comunicación, el conocimiento y las acciones) y la realidad en la ficción (es decir, los mecanismos del procedimiento ficticio); 2) ficcionalización y religión, en la que el enfoque será indicar qué es ficcionalizado en la religión y qué es religioso en 
la ficción; y, finalmente, 3) sugerir algunas interpelaciones de la ficción literaria a la religión, cuando, entonces, pretendemos plantear la cuestión del horizonte humanista. De esta forma, esperamos contribuir a una mirada renovada a los textos religiosos y su acogida en la literatura.

Palavras claves: ficcionalización; religion; literatura; lenguages de la religion; teopoética.

\section{Introdução}

Ainda hoje, não é incomum que o romance, o drama ou a poesia, quando não reduzidos ao lugar-comum de puro entretenimento (não que eles não possam entreter!), sejam vistos como uma forma inferior de acesso à realidade. Isto, em parte, se deve a certo movimento da própria teoria da literatura que, ligada a algumas vanguardas artísticas e no afã de ganhar cidadania universitária, circunscreveu as possibilidades dos textos literários à sua lógica interna. Entretanto, a noção de que a literatura é menos importante se comparada a construtos teóricos também é consequência direta do modelo filosófico racionalista (em sentido amplo) que se consolidou a partir da oposição entre realidade e ficção.

Nos estudos literários e na teologia, aos poucos, estas posturas passaram a ser reconsideradas. No caso dos críticos e teóricos da literatura, o interesse pela relação entre religião/teologia e literatura decorre justamente do esgotamento das metodologias excessivamente formalistas, enquanto nos estudos teológicos ele está ligado ao desgaste da linguagem tradicional da fé. Desde a segunda metade do século XX, alguns teólogos/as vêm tentando chamar a atenção para a importância das manifestações artísticas, dentre elas a literatura como forma de ressignificar a teologia em resposta à crise da metafísica.

No campo católico, na Europa, num primeiro momento, ganharam destaque os nomes de Henri De Lubac, Romano Guardini, Hans Urs von Balthasar, Karl Rahner, Pie Duployé, entre outros. Entretanto, o tema ganha mais notoriedade no Vaticano II (cf. Gaudium et Spes), e já na década de 70, é publicado um número da revista Concilium dedicado ao assunto, organizado por Johan-Baptist Metz e Jean-Pierre Jossua. No âmbito protestante europeu e estadunidense, a contribuição de Paul Tillich foi fundamental para uma aproximação teológica à literatura; mas também não podemos deixar de mencionar os esforços de Dorothe Sölle e Amos Wilder. Dos anos 1970 em diante, muitos/as outros/as estiveram engajados na produção de textos sobre o assunto (Hans Küng e Karl Josef-Kuschel, por exemplo). Na América Latina, teólogos como Juan Carlos Scannone, Pedro Trigo, Gustavo Gutiérrez 
e Luis N. Rivera-Pagán escreveram sobre a relação entre teologia e literatura. Mais especificamente no Brasil, seria possível ressaltar, num período inicial, as discussões de Rubem Alves em $A$ Gestação do Futuro sobre o valor da imaginação perante a absolutização de certos projetos utópicos - livro que lhe rendeu desqualificações por parte de alguns teólogos da libertação.

Grosso modo, boa parte dessas reflexões estavam, de um lado, pouco preocupadas com questões específicas da teoria e da crítica literárias, e, de outro, muito submetidas a cacoetes confessionais que reduziam a literatura à condição de acessório no método teológico. Posteriormente, na década de 1990, abrindo novos caminhos, temos o livro de Antônio Manzatto sobre os romances de Jorge Amado; no princípio dos 2000, Deus no espelho das palavras, de Antonio Magalhães; e poucos anos depois, a publicação da tese de José Carlos Barcellos; nesse ínterim, alguns livros organizados por Maria Clara Bingemer e Eliana Yunes, ambas da PUC-Rio, além dos esforços de Salma Ferraz, na UFSC, também expandiram esta reflexão. Além desses trabalhos que ajudaram - com seus limites e potencialidades - a lançar as bases para as pesquisas que se seguiram, a formação da ALALITE (2006) contribuiu para consolidar uma rede de pesquisadores/as em torno do tema.

Hoje, contando também com os grupos da área "Linguística e Literatura" que estudam a interface religião/literatura, o número nacional é semelhante ao resultado da soma dos grupos nos EUA, na Europa e no restante da América Latina. Há GTs com esse recorte nos congressos de associações/sociedades importantes como SOTER, ANPTECRE, ANPOLL, ABRALIC. A quantidade de artigos, dissertações e teses cresceu significativamente a ponto de se tornar inabarcável. Além de um periódico especializado - Teoliterária -, com 3 números anuais, só em 2020 foram publicados em revistas dos estratos A1, A2 e B1 quatro dossiês com essa temática, no Brasil.

Essas pesquisas compõem um campo de conhecimento que tem sido chamado de Teopoética; campo esse que, embora inicialmente tenha nascido do diálogo entre Teologia e Literatura, se desenvolve com renovado fôlego nas Ciências da Religião, especialmente no âmbito do estudos das linguagens da religião em diálogo com os estudos literários, desdobrando-se em uma gama de modelos epistemológicos e diversidade de objetos que englobam, hoje, poesia, romance, teatro, literatura de cordel, cinema, música, grafite, HQs, textos religiosos, suas recepções na arte, etc.

Admitindo a teopoética, então, também como parte das ciências da religião, especialmente no projeto dos estudos das linguagens da religião, ainda 
precisamos nos perguntar sobre o que distingue esse tipo de abordagem ${ }^{1}$. Nos estudos de literatura, a religião pode "aparecer" como algo que auxilia na hermenêutica de um texto literário e até mesmo como parte fundamental da teoria da literatura - como no ambicioso projeto de Anatomia da crítica, de Northrop Frye -, mas o foco é o fenômeno literário, suas formas e conteúdos.

Na teologia, por mais interdisciplinar que seja o método, muitas vezes, ele propõe uma aproximação à literatura desde a noção de uma revelação plasmada em uma confissão específica; ou seja, como na proposta de Kuschel, presume-se um núcleo de fé que, no diálogo, baliza a avaliação das ideias teológicas mobilizadas pelos/as escritores/as. Evidentemente, alguns trabalhos ocupam uma zona fronteiriça porque se articulam a partir de princípios de hermenêutica literária para chegar a uma teologia. O caso de José Carlos Barcellos é um bom exemplo disso. Ele mesmo declara em tom de confissão: "o nosso [método], sendo fundamentalmente crítica literária, só pode ser considerado teologia na medida em que é (...) um esforço para se levar à linguagem conceitual o pensamento teológico de Julien Green” (BARCELLOS, 2008, p. 143).

Nas ciências da religião, o interesse recai sobre a literatura enquanto produtora de uma linguagem religiosa - mesmo que de forma tensionada - e sobre a teoria literária enquanto aporte para o estudo dos textos religiosos. Isto demanda uma postura interdisciplinar. Por um lado, o estudo da linguagem artístico-literária e das suas relações - de dependência e antagonismo, apropriação e reelaboração - com as linguagens religiosas solicita uma compreensão das questões históricas, formais, intertextuais e culturais que perpassam os romances, contos, dramas e poemas; por outro lado, o estudo dos textos religiosos também pode ganhar muito com a teoria da literatura já que, ressaltadas algumas diferenças, eles partilham de artifícios da criação literária. Este tipo de abordagem é análogo àqueles que têm sido praticados em outras áreas, como, por exemplo, na antropologia ou sociologia; nestes casos, com métodos próprios, o uso do material literário se destina à compreensão do campo em exercício. Esta aproximação pode enriquecer tanto a compreensão do texto literário em questão quanto da área do saber que procura dialogar com ele. Faria apenas a seguinte ressalva: muitas vezes, os trabalhos mais produtivos são aqueles que centram esforços em iluminar com maior intensidade a própria relação religião/literatura do

1 Confira: Linguagens da Religião (2012) e Religião e Linguagem (2015). 
que um de seus polos; ou seja, que pensam esse diálogo entre literatura e religião levando em conta uma irredutível tensão. De todo modo, para dizer o mínimo, esta perspectiva ainda que vetorizada pela preocupação de cada esfera peculiar, sem dúvida, mitiga os efeitos da hiperespecialização que marca a organização do saber universitário. No entanto, me permito, aqui, uma provocação. Ainda que considere a discussão da especificidade importante, ressaltaria a necessidade de adentrá-la atentando para o horizonte mais amplo das humanidades. Em nosso entendimento, deveríamos tomar cuidado para que a teopoética não se tornasse autocentrada. Isto é, seria necessário cuidar para que o interesse que antes denotava uma abertura à complexidade não seja revertido para uma técnica ou vocabulário particular, que só especialistas são capazes de decifrar. Em outras palavras, seria interessante dar um sentido humanístico à tepoética. Obviamente, não propomos isto baseados na ideia de uma "essência" humana, mas, a partir das críticas que procuraram repensar o humanismo como algo submetido à contingência, aberto e democrático - mais do que qualquer outra coisa, como um processo de autocrítica e incessante descoberta contra ideias prontas e clichês, sejam eles de que caráter forem.

Nosso objetivo principal, portanto, a partir desse momento, é mostrar como a ficcionalização (mais ou menos consciente) é um procedimento compartilhado pela religião e pela literatura, tendo inclusive bases antropológicas, se constituindo em uma forma fundamental de conhecimento (BOYD, 2009; BOYER, 2001). Evidentemente, ainda que consideremos tais afinidades, não ignoramos as diferenças existentes entre religião e literatura. Nesse sentido, propomos um percurso argumentativo a partir dos seguintes passos: 1) ficcionalização, conhecimento e realidade - onde buscaremos mostrar a ficção na realidade (i.e. a ficcionalização como elemento básico da comunicação, do conhecimento e das ações) e a realidade na ficção (i.e. os mecanismos do procedimento ficcional);

2) ficcionalização e religião - em que o foco será indicar o que há de ficcionalização na religião e o que há de religioso na ficção; e, por fim, 3) aventar algumas interpelações da ficção literária à religião - quando, então, pretendemos colocar a questão do horizonte humanístico.

\section{Ficcionalização e realidade}

\section{I. A ficção na realidade}

Não é novidade a desconfiança em relação à ficção, e sempre que o assunto é tratado recorda-se a suspeição herdada por Platão para com a 
poesia, a ponto de recomendar a sua expulsão da república ideal. Segundo a interpretação mais corrente, era necessário que a racionalidade conquistasse seu espaço frente àquilo que o filósofo considerou a aceitação, por assim dizer, sem muito esforço, da fantasia. O espaço dado a certa poesia deveria ser subtraído, já que, na formação grega, ela conduzia ao engano e não à razão. Ao longo do percurso argumentativo da República, o Sócrates platônico chega à conclusão de que o poeta é um mentiroso. Ainda que estudos, como o de Luc Brisson (2014), tenham ressaltado que, no fundo, a crítica de Platão é direcionada a um tipo específico de mimesis e de religião que ocupavam um lugar central na paideia grega, no âmbito do discurso sobre o Ser, a tese de que a flexibilidade da linguagem, que abrigava o contraditório, deveria ser eliminada para que a verdade pudesse ser contemplada para além das aparências, parece ter ganhado força.

Avançando um pouco mais, podemos mencionar o caso de St. Agostinho que, como observa Brian Stock (STOCK, 2007, pp. 2-3), se apropria dos meios literários considerados pagãos pelo cristianismo hegemônico, mas não deixa de demonstrar seu incômodo com o prestígio que estas expressões possuíam na formação dos jovens. Nas Confissões (I, XIII), o padre latino menciona, com constrangimento, o fato de ele próprio ter se emocionado com a morte da rainha Dido ao ler a Eneida, o que o distraía de conhecer a sua condição ontológica de pecador. É claro que a relação de St. Agostinho com aquilo que chamamos modernamente de literatura não pode ser reduzida a um antagonismo, mas também consideramos necessário apontar os limites que ele próprio demarcou.

Essa postura crítica em relação à ficção ganha feitios distintos, e, mesmo com a consolidação da apropriação do instrumental aristotélico, ela permanece. Progressivamente, com a tradução do corpus aristotélico, a lógica passa a presidir a preocupação de muitos filósofos medievais que acreditaram ser esse o modo de sanar as contradições de certa apropriação simbólica das escrituras e da imaginação sem rédeas. A tarefa do pensamento era sobretudo fixar um significado preciso para os vocábulos e, por essa razão, em boa parte da filosofia e da teologia a dicção passa a ser plasmada pela lógica. Por exemplo, ao recorrer ao princípio da não contradição já utilizado no domínio das ciências jurídicas, Abelardo insiste na necessidade da conversão da teologia à inteligibilidade pelo recurso à lógica (CHENU, 1957, pp. 18-26). A produção teológica que se segue está em grande parte eivada desse gosto pelo "rigor técnico" e pela "explicação exaustiva", que 
encontrará sua expressão mais alta nas sínteses doutrinais do século XIII, revisadas posteriormente na segunda escolástica.

Mesmo sob pena de simplificar demais as coisas, é possível perceber que essa desqualificação do ficcional se desdobra de maneiras diversas no pensamento ocidental, em que pese toda a precariedade dessa expressão. Não nos parece forçoso dizer que a oposição entre o imaginativo-ficcional e o filosófico-racional esteve, por exemplo, no centro da preocupação da teoria moderna do conhecimento (Descartes, Bacon, Hume, etc). É curioso que em seu relato sobre o processo da tomada de consciência do Cogito, René Descartes, em seu Discurso do Método, tenha mudado de opinião sobre serem "as letras" fonte de "conhecimento claro e seguro", tendo, portanto, abandonado o "estudo das letras" (DESCARTES, 1977, p.21). Desta forma se inaugura na modernidade uma cisão entre conhecimento verdadeiro, científico (na linguagem das matemáticas, segundo Descartes) e o conhecimento que se obtém pela literatura.

No entanto, o reconhecimento do valor do ficcional ganha contornos específicos em Bentham (sec. XVII), em muitos autores do romantismo (XVIII e XIX), em Nietzsche (sec. XIX), e, no decorrer do século XX, especialmente depois do "giro linguístico". Num regime de fratura do nexo ontológico entre as palavras e as coisas, a ficcionalidade passa também a ser a condição ineludível para o acesso à textura da existência. Em outras palavras, a antinomia de fundo, realidade versus ficção, perde força; sob este novo ângulo, a ficcionalização se revela um aparato inerente à toda e qualquer formulação de saber e comunicação. A ciência e a filosofia se tornam gêneros literários; e a literatura, por sua vez, passa a categoria de gênero de sondagem das possibilidades humanas.

Obviamente, não se trata de negar a realidade que se impõe ou mesmo a validade do saber científico. Mas de considerar que não há como viver fora da modelação do mundo pela linguagem. Mesmo nas narrativas que não querem ser explicitamente ficcionais, o trabalho imaginativo de seleção interpretativa de uma série de acontecimentos é condição inescapável. Mais ou menos conscientes disso, tais narrativas submetem, ainda que num primeiro nível, as coisas e o fluxo caótico dos eventos à linguagem.

Nossa leitura da (micro ou macro) história depende de artifícios ficcionais. Tendemos a ler a nossa vida e a dos outros como um enredo "romanesco". Em alguns casos, isto só se torna mais evidente em situações que nos atam às pontas de nossa própria existência. Umberto Eco narra a 
experiência de ter sido surpreendido, no planetário do Museu da Ciência, em La Coruña, com a reprodução do céu da sua cidade natal na noite de seu nascimento. E comenta: "era ficção porque a história fora reinventada pelo curador; era História porque recontava o que acontecera no cosmos num momento do passado (...) Por um instante, fui o leitor modelo do Livro dos Livros" (ECO, 1994, p. 147). O relato de Eco nos remete à intepretação do mundo como um livro, objeto que materializa a articulação intelectiva entre passado e presente, estrutura básica do pensamento narrativo.

Aqui, poderíamos evocar uma ligeira afinidade com a ideias de Hayden White quando destacou a História enquanto "artefato literário" (2001). Ou seja, a vida imediata é opaca e por isso mesmo dependemos de esquemas narrativos e formas literárias que, implicitamente, segmentam, selecionam e organizam a realidade. Se sabemos que Napoleão morreu em Santa Helena, tudo mais que confere sentido a isso depende de nossa narração. Por outras palavras, a condição do conhecimento é a ficcionalização; temos necessidade desta para chegar àquele. Michel de Certeau também parece enfatizar isto. Em História e Psicanálise: entre ciência e fiçãao, ele busca alargar as qualidades do ficcional para além da "literatura". Não sem deixar de tornar um tanto fluído o termo "ficção", Certeau lança mão de uma caracterização que abarca o mito, a escrita literária e o discurso científico. Salienta que há uma disposição metafórica em cada uma dessas modalidades discursivas - característica que constitui uma astúcia face ao poder e confere potencial de subversão a elas (CERTEAU, 2016, p. 96).

Por esse viés, a ficcionalização estaria presente não só na literatura, mas na religião como recurso para a composição do mito, na ciência como expediente para a formulação de hipóteses e construtos teóricos, e nas etapas imaginativas que antecedem as nossas tomadas de decisão. Aliás, há quem defenda que foi justamente por essa capacidade de imaginar os perigos do mundo pré-histórico - é claro, não sem a repetição do trauma nos ritos sacrificiais que está na base do surgimento da religião - que chegamos até aqui (TÜRCKE, 2010).

Por fim, gostaríamos de fazer apenas referência a estudos das ciências cognitivas que reconhecem o papel da ficção, da narrativa e das conexões metafóricas na constituição das estruturas cognitivas humanas. Segundo Terrence Deacon, a linguagem surge na evolução do Homo Sapiens como forma de explicar e dar sentido ao mundo e isso acontece nas primeiras formas da narrativa, dentre elas, no mito (DEACON, 1998). A ficção e criação 
das primeiras histórias também exerceram papel fundamental na evolução humana segundo Brian Boyd (2009). Por fim, há estudos sobre o papel das metáforas na criação de projeções (parábolas), de núcleos de narrativas, que determinam nossa construção de mundo (TURNER, 1996).

\section{I.II. A realidade na ficção}

Wolfgang Iser, teórico da ficção fundamental para esta reflexão², parte de uma provocação semelhante quanto às fronteiras entre ficção e realidade: "são os textos ficcionais realmente tão fictícios e aqueles que não se podem assim descrever são de fato isentos de ficções?" (ISER, 2006, p. 13). Mas a partir desta indagação propõe a superação da dicotomia realidade/ ficção através da tríade "real, fictício e imaginário". A ficção literária, como "ato de fingir" deliberado, desrealiza o real e realiza o imaginário, transgredindo os seus limites. Ficção é fricção do imaginário com o real, isto é, o imaginário, difuso e fluido, se torna real na ficção, na medida em que a realidade é tornada signo. Para lembrar o título de Vargas Llosa, "a verdade das mentiras" ficcionais se oferece por meio de uma argúcia que seleciona uma parcela da realidade (seleção), desloca-a de sua estrutura original, combina-a com outros elementos textuais (combinação) e se desnuda indicando sua ficcionalidade (indicação). É assim que ela digere a realidade à sua maneira para dar vida ao mundo próprio da imaginação. Assim, um cumprimento que no dia a dia possui uma função comunicativa corriqueira, na ficção, "transgride o ritual do cotidiano, dando-lhe outra função (...). A formulação do cumprimento é estritamente a mesma. A ela, contudo, se abre um horizonte de possibilidades" (LIMA, 2011, p. 283). É nesse sentido que poderíamos dizer que o cumprimento é irrealizado, transgredido, desautomazido de sua função ordinária para ganhar novas possibilidades. O trabalho ficcional, como sublinha Iser, retira as convenções que organizam a vida do seu contexto para submetê-las ao escrutínio: "nas ficções literárias, os mundos existentes se sobrepõem e, apesar de ainda serem reconhecidos individualmente, estão postos em um contexto que os desfamiliariza" (ISER, 2004, p. 01). Entretanto, a ficção literária "desnuda a sua ficcionalidade"; e assim se diferencia daquelas que fundam o "estabelecimento de instituições, sociedades e imagens de mundo” (ISER, 1996, p. 23-4). A ficção literária se autoevidencia não como representação da realidade, mas como apresentação

2 Evidentemente, outros tantos autores e autoras contribuíram para a teorização da ficção, como Erich Auerbach, Nelson Goodman, Luiz Costa Lima. 
desmistificante desta. Consciente de que todo acesso ao real é também uma espécie de desenho, a ficção propõe um outro desenho assumindo-se sempre como desenho.

Estas questões se tornam mais evidentes quando adentramos alguns textos ficcionais. Não queremos, com isso, afirmar que eles ilustram a teoria e tampouco se equivalem. A singularidade de cada um deve ser assegurada para não caírmos na armadilha das perspectivas essencializadas. Quer dizer, de nossa parte, não há qualquer interesse em "capturar" a substância da ficção. Aliás, estamos conscientes de que os termos ficção e literatura não são auto-evidentes. Entretanto, os textos que destacaremos a seguir, por serem criações que contém elementos de meta-ficção, nos ajudam a esclarecer certos pontos da relação realidade/ficção.

O interessante trecho do Livro das Postagens, de Carlito Azevedo, sublinha com agudeza a complexa relação da ficção com a realidade:

O que os poetas dizem sobre o amor é tão enganador como quando num antiquário se lê num letreiro: "Passa-se a ferro". Não leve sua camisa para ser passada ali, o letreiro está à venda (AZEVEDO, 2016, p. 62).

Carlito não está longe de Pessoa quando este escreve: “O poeta é um fingidor". Ambos, talvez, estejam a nos lembrar justamente o paradoxo da criação artística, que só pode nos dizer a verdade fingindo, enganando. Aliás, como já destacado por muitos, o verbo fingir está etimologicamente ligado ao verbo modelar. $\mathrm{O}$ romancista, poeta ou pintor, portanto, quando modela, finge a realidade que está plasmando (ORDINE, 2017, p.161).

O mesmo Pessoa continua a nos fornecer caminhos para pensar as astúcias da ficção quando, na sua obra em prosa, afirma: "Sou como um quarto com inúmeros espelhos fantásticos" (PESSOA, 2005, p. 81). De imediato, para aqueles que conhecem um pouco o autor, a frase é vista como indício do fenômeno da heteronímia, recurso que foi uma das grandes invenções pessoanas e que tornou conhecidos nomes como Álvaro de Campos, Alberto Caeiro e Ricardo Reis - cada um deles portadores de personalidades e visões peculiares de mundo. No entanto, se quisermos levar ainda mais adiante a imagem, poderíamos nos perguntar se, com isso, Pessoa não está indicando: a) um questionamento contundente dos fundamentos em que se assentam a nossa identidade e por conseguinte a nossa relação com o 
mundo; b) afirmando a ficção como modo inescapável de relação com o real. A imagem de um cômodo povoado de espelhos, que sugere uma projeção indefinida de reflexos, pode ser associada aos muitos "eus" do poeta, mas também à própria experiência ficcional.

Este é um dos pontos centrais em boa parte da criação ficcional e, em Pessoa, já estava prefigurado no texto da peça: O Marinheiro (2020), publicado inicialmente em 1912. O drama conta a história de três mulheres que, numa torre circular, velam o corpo de uma quarta. Enquanto o fazem, conversam sobre a vida, até que uma delas passa a narrar um sonho sobre um marinheiro que havia se perdido em alto-mar e se abrigado em uma ilha deserta. O marinheiro do sonho passa a sonhar com a sua terra e a modifica. Aos poucos ele mesmo vai se tornando um outro apegado à sua fantasia. A terra que habita é seu sonho e sua realidade natal é agora mais distante. Um dia passa pela ilha um navio e não encontra mais o marinheiro. Teria ele voltado à sua origem? Qual? A real ou a do sonho? Neste momento, as veladoras são arrastadas para um dilema: Por que não seriam elas mesmas criações do marinheiro? A realidade e substância de seu mundo não seria precisamente aquela do sonho do náufrago?

$\mathrm{O}$ argumento de Pessoa se desenrola colocando em xeque as distinções claras entre o estado vigília e o sonhado. Haquira Osakabe descreve assim o notável expediente do poeta: "Pessoa cria as veladoras e uma delas "cria" o marinheiro que cria um mundo de gentes, onde pode estar criada uma das veladoras que foram criadas por Pessoa" (OSAKABE, 2013, p. 41). Numa espécie de subversão da alegoria platônica da caverna, em que não há como saber se o fora de uma caverna é o interior de outra, Pessoa esgarça a consciência de seu leitor levando-o à dúvida radical. Tudo o que as irmãs veladoras podem expressar são perguntas sem respostas: "quem é que nos faz continuar falando?" e "Quem é que estou sendo?... Quem é que está falando com a minha voz?...” (PESSOA, 1986, p.164). Se em Descartes a dúvida cética é posta em função do cogito como certeza primeira, no drama pessoano não há subterfúgios a não ser a própria imaginação. O efeito da leitura é a suspensão do juízo sobre o próprio mundo (LOPES; CÔRTES in: PESSOA, 2020, pp. 18-19).

Esta construção do sonho dentro do sonho, que, diga-se de passagem, aparece em outros/as escritores/as, empresta à ficção força e responsabilidade. Quando Dom Quixote subitamente ataca o teatro de bonecos de mestre Pedro por não saber mais distinguir o real da fantasia, ou 
quando, em As ruínas circulares, o personagem borgeano que cria sonhando, ao caminhar em direção ao fogo e não ser fustigado pelas chamas se dá conta de que era também o sonho de outrem, não estamos novamente, aqui, no quarto de muitos espelhos fantásticos, que simbolizam ao mesmo tempo a precariedade da linguagem e a sua potência?

Para citar apenas mais um exemplo que, de alguma forma, contém as questões mais importantes do percurso argumentativo deste tópico, lembro do conto o Aleph, de Borges. Quando o personagem homônimo do autor contempla o Aleph - ponto que abarca toda a realidade sem sobreposições, diz: "Toda linguagem é um alfabeto de símbolos cujo exercício pressupõe um passado que os interlocutores compartilham; como transmitir aos outros o infinito Aleph que minha temerosa memória mal consegue abarcar?" (BORGES, 2007, p. 148). E logo em seguida, ao submeter a visão da totalidade simultânea à inevitável contingência da linguagem, o Borges criado por Borges afirma: "vi no Aleph a Terra, e na Terra outra vez o Aleph e no Aleph a Terra, vi meu rosto e minhas vísceras, vi teu rosto, e senti vertigem e chorei (...)" (Ibid., p. 150). Chamo a atenção para o pronome que denota que o narrador-personagem se dirige, agora, ao leitor. Estamos no coração da mecânica ficcional amplificada: Borges-autor cria Borges-narrador-personagem e o Aleph; Borges-narrador-personagem vê, no Aleph, o mundo do leitor. Se o Aleph, ponto que guarda tudo e todos simultaneamente sem sobreposições, é visto dentro da ficção, a ficção já não é a realidade? Permanecemos sem escapatória no do jogo do auto espelhamento, que, engolindo a realidade e sendo engolida por ela, nos faz estranhá-la; provoca uma rachadura na nossa relação com ela. É justamente por essa fenda que uma luz pode entrar.

\section{Ficcionalização e religião}

\section{II.I. Ficcionalização na religião}

Não há como ignorar que a religião se articula também desde um fundo imaginativo. Os mitos estão cheios de elementos fantásticos e insólitos. Basta uma rápida olhada nas súmulas de mitologia para nos darmos conta da quantidade enorme de heróis com poderes sobre-humanos, seres sobrenaturais, animais falantes, entre outras coisas, como mundos celestiais, infernais e intermediários. Evidentemente, precisamos considerar que, de modo distinto do romance - como já destacamos a partir das teses de Iser - o mito não "desnuda a sua ficcionalidade”. Mas poderíamos nos perguntar, 
apenas para citar alguns exemplos, o que seria dos textos proféticos sem a força das imagens, ou, o que seria dos textos apocalípticos sem o recurso da imaginação. Não é a parábola uma ficção que, em princípio, começa por estabelecer uma relação muito próxima com o cotidiano, mas, a um dado momento, deixa de fazer sentido à luz dos conceitos e da lógica estabelecida? Mesmo nos relatos que pretendem indicar sua própria historicidade, temos uma série de sinais que nos levam a considerá-los, na expressão de Robert Alter: "ficções historicizadas" (ALTER, 2007, p. 71). Obviamente, não se trata de dizer que os processos de formação dos textos ficcionais, hoje, são idênticos àqueles que fizeram nascer o mito, a profecia, os apocalipses, as parábolas. No entanto, nem por isso, tais textos deixam de estar compartilhar aspectos da mecânica ficcional. Assim como a tragédia grega, o romance medieval de cavalaria, o teatro de Shakespeare e o romance moderno, eles lidam com aspectos particulares de suas realidades também por meio da seleção e da combinação. Ou seja, mesmo que os textos não sejam fruto de autores e redatores conscientes de sua ficcionalidade, o processo de modelamento do mundo é semelhante. José Tolentino Mendonça (2009, pp. 298-299), tratando do caráter literário das escrituras hebraicas e cristãs, ressalta que "importa menos o modo como a Bíblia chegou à literatura, do que o reconhecimento de que os seus autores trabalharam a língua escolhendo ou criando formas literárias nas mesmas condições aplicáveis à literatura em geral". Se, por um lado, é certo que não há nos textos sagrados a mesma aspiração que temos num conto contemporâneo porque sua intenção inscreve-se no domínio, por assim dizer, querigmático, por outro, eles possuem uma dimensão ficcional pela maneira como, apelando aos recursos disponíveis na linguagem, "fingem" a realidade. Isto é, a religião propõe uma realidade. Entretanto, ainda assim, no movimento imaginativo de constituição de mundos, o discurso religioso é também um discurso carregado de ficcionalidade.

\section{II. Religião na ficcionalização}

Em parte, a presença de elementos da religião na ficcionalização pode ser explicada pela própria relação imemorial entre arte e religião. Historiadores da arte, semiologistas e antropólogos tem destacado que as formas simbólicas que deram origem ao rito e ao mito tiveram um papel decisivo no desenvolvimento da linguagem e da cultura humanas. As pinturas de Chauvet, Lascaux, Altamira, La Pasiega, etc, provavelmente foram 
elaboradas numa atmosfera de "encantamento", de rituais com transe (estados alterados de consciência) religioso (LEWIS-WILLIAMS, 2002). As melodias das chamadas Songlines, uma espécie de mapa baseado em antigas canções aborígenes australianas, que, quando cantadas, permitem uma locomoção segura aos grupos seminômades fornecem reatualizam a geografia sagrada dos mitos (QUINTAIS, 2012).

Segundo Northrop Frye e Eleazar Meletinsky, a arte em geral, e a literatura em particular, atualizam adaptam (no dizer de Frye "deslocam") elementos do mito. Ele o expressa de maneira perspicaz ao afirmar que em se tratando de literatura tudo é ao mesmo tempo novo e reconhecível (FRYE, 2017, p. 38). Não à toa, por exemplo, Melville gasta a tinta de sua pena para mostrar como sua enorme baleia pertence à estirpe de monstros presentes nos mitos gregos e bíblicos.

No entanto, por mais que possamos afirmar que a literatura deriva seus motivos e modos de formas simbólicas gestadas no seio da religião, estamos longe de sugerir que este processo de apropriação do mito é algo simples. Isto é, a literatura não está isenta dos conflitos e transformações sociais. Os deuses e heróis dos mitos antigos, aos poucos, dão lugar aos personagens humanos. O próprio Frye reconhece que, se "em Shakespeare ainda nos deparamos com heróis que veem fantasmas e se expressam em magnífica poesia, (...) no tempo de Esperando Godot, de Samuel Beckett, os personagens já falam em prosa e são eles mesmos fantasmas" (Ibid., p. 49). Este destaque é importante para percebermos que a operação ficcional não pode ser reduzida à religião e vice-versa. O longo processo de emancipação da arte em relação à religião produziu, por exemplo, uma afirmação da autonomia das duas esferas, ainda que, em alguns casos, certas expressões literárias tenham procurado criar um novo sagrado face às religiões institucionais (PAZ, 2012, p. 124). A literatura passa a ser entendida uma criação laica, que não pretende negar a incompreensibilidade e o mistério do mundo, mas que se afirma sem o compromisso com qualquer espécie de doutrina. O romance moderno - e Dom Quixote como seu grande representante - se destacaria por ser essencialmente antidogmático. Em razão de sua estrutura, seria capaz de problematizar a opinião dominante e a teoria como fechamento definitivo do real. Sua ótica não estaria limitada a expressar certa visão, mas criaria um cruzamento permanente entre diferentes perspectivas e tipos de juízo. Nesse sentido, é interessante recordar a maneira como Milan Kundera, em $A$ arte do romance, se refere ao romance (2009, pp.13-14): 
Quando Deus deixava lentamente o lugar de onde tinha dirigido o universo e a sua ordem de valores, separara o bem do mal e dera um sentido a cada coisa, Dom Quixote saiu de sua casa e não teve mais condições de reconhecer o mundo. Este, na ausência do juiz supremo, surgiu subitamente numa terrível ambiguidade; a única Verdade divina se decompôs em centenas de verdades relativas que os homens dividiram entre si. Assim, o mundo dos tempos modernos nasceu e, com ele, o romance, sua imagem e modelo.

No entanto, mesmo considerando essa autonomia da literatura, podemos afirmar que sobrevivem elementos da religião na ficção também num segundo nível; isto é, num nível distinto daquele que apontamos anteriormente - da inevitável dependência que se reflete na materialidade literária. O crítico James Wood explica, por exemplo, que, na arte romanesca, se processa uma alternância constante entre a modalidade secular e a religiosa (WOOD, 2012, p. 18). O impulso secular do romance procura expandir a vida, ampliar as suas possibilidades, muitas vezes contra as certezas religiosas. É o que Kundera também sublinha quando afirma que a ficção romanesca, a exemplo de Penélope, "desfaz durante a noite a tapeçaria que os teólogos, os filósofos e sábios urdiram na véspera" (KUNDERA, 2009, p. 148).

Mas a modalidade religiosa do romance recorda-nos também que, assim como nas narrativas religiosas, toda ficção, não só oferece um conhecimento do mundo, como também projeta outros mundos. Ao mesmo tempo em que ela é uma apresentação - e não representação! - da realidade, um verdadeiro lugar de reencontro do ser humano com valores coletivos, não deixa de ser uma reserva semântica. Por isso mesmo, toda obra ficcional solicita do leitor uma espécie de "fé". Para que possamos acessar essa reserva de sentido, como já há muito enfatizado pelo poeta Samuel Taylor Coleridge, a literatura exige um "momento de voluntária suspensão da incredulidade" (COLERIDGE, 1991, p. 236). É uma espécie de confiança de base na aproximação à página do texto, sem a qual não seria possível a experiência de identificação. Esta "fé ficcional", este "salto" na direção do mundo da obra, amplia o campo da nossa experiência porque faz-nos viver e conhecer coisas que, de outro modo, jamais viveríamos e conheceríamos. Entretanto, é preciso considerar mais uma vez a diferença entre a ficção literária e a religião, porque "a ficção pede-nos que acreditemos, mas a qualquer momento podemos escolher não acreditar. (...) Sabe que a qualquer momento os seus argumentos podem falhar" (WOOD, 2012, p. 18). Ou seja, o leitor só poderá transpor o limiar 
da "mentira", da "ilusão", se e somente se, num exercício fiducial, entregarse ao mundo da obra. Todavia, esta mesma obra pede que se duvide dela.

Depois deste breve percurso em que procuramos pensar as proximidades entre religião e literatura sem ignorar as devidas distinções, acreditamos que estamos em condições de pensar com mais cuidado algumas interpelações que a segunda faz a primeira para, então, recolocar a questão do estudo da literatura num horizonte humanístico desessencializado.

\section{Interpelações da ficção literária à religião}

Pressuposta uma diferença entre essas esferas, ficção literária e religião, a imagem dos espelhos mais uma vez nos auxilia ${ }^{3}$. Se a metáfora especular, na metafísica cristã (cf. I Coríntios 13,12), por exemplo, é promessa e sinal de um desvelamento cabal, podemos dizer que sua multiplicação no jogo ostensivo da ficção põe em xeque a ideia de uma explicação "bem-acabada" da realidade. A religião contém a expectativa do sentido último que transcende a contingência; a ficção é, não raras vezes, como afirma Richard Rorty, uma tentativa de conseguir "autocriação" por meio da consideração da contingência (RORTY, 1990, p. 10). Na visão mítico-religiosa, o significado depende da noção de uma organização decorrente da criação divina, de onde se extraem consequências morais. A razão ficcional, por meio do processo de seleção, combinação e auto-desnudamento de sua particularidade, proporciona ao leitor a possibilidade de espreitar múltiplas histórias e diversos pontos de vista. Por esse motivo, para Rorty, num regime de reconhecimento do potencial e da fragilidade da linguagem, a criação literária seria uma alternativa concreta ao pensamento religioso e à investigação metafísica racionalista. O filósofo se aproxima do entendimento do crítico Lionel Trilling quando este afirma que o romance ensinou a extensão da variedade humana e sua pluralidade ética, nos séculos XIX e XX, especialmente frente às metanarrativas religiosas e aos utopismos políticos que acabaram, em nome de boas intenções, convertendo o outro em objeto de coerção. Uma das principais funções da ficção, portanto, seria a de alargar a nossa "imaginação moral" (TRILLING, 2015, p. 266). Esta expressão, inclusive, é retomada por

\footnotetext{
Ver a perspicaz comparação entre a imagem do espelho em I Coríntios 13 e a obra de Fernando Pessoa feita por Marcos Lopes e Ana Maria Ferreira Côrtes na introdução ao texto da peça $O$ Marinheiro.
} 
Paulo Nogueira

Rorty para esclarecer o valor da literatura. Para ele, a literatura contribui para o prolongamento de nossa imaginação moral, porque aprofunda nossa percepção das diferenças existentes entre as pessoas e a variedade de suas necessidades (RORTY, 2002, p. 158-159).

Ora, portanto, a ficção pode ser uma reserva semântica desde a qual problematizamos a nossa condição, ou seja, a experiência de leitura confronta as nossas estereotipizações e certezas, sejam elas de cunho religioso ou filosófico. No entanto, uma questão basilar se impõe a partir da crítica rortyana às concepções religiosa e filosófica (metafísica) de mundo: a eliminação de uma fundamentação transcendental, seja religiosa ou filosófica, nos empurraria necessariamente ao niilismo? Estaríamos, a partir disso, condenados a uma existência fútil, na melhor das hipóteses, e, na pior, ao caos?

Em Contingência, ironia e solidariedade (2007), Rorty procura responder a essas perguntas, e expõe de maneira matizada sua noção alternativa a respeito da abrangência cognitiva e moral da criação ficcional. Fazendo uma incursão nas obras de romancistas como Nabokov e Orwell, ele defende a ideia de que nossos comportamentos morais são consequência mais do contato com experiências humanas concretas do que de um aprendizado de tipo filosófico, baseado em inquirições lógicas e abstratas. Os argumentos filosóficos sobre a imoralidade das sociedades escravocratas, por exemplo, de acordo com Rorty, contribuíram de forma insuficiente para a abolição dessa injustiça; já os relatos sobre as crueldades cometidas contra os/as escravos/ as, por sua vez, comoveram as pessoas e promoveram uma empatia capaz de mudar a mentalidade de muitos/as sobre o assunto. A ficção, por seu caráter intrinsecamente ligado à estética, seria uma forma de razão sensível, capaz de recorrer às emoções e promover a compaixão, criando assim uma solidariedade pública.

O caso de Amada, de Toni Morrison, é um bom exemplo de como a ficção, por meio de seus recursos próprios, nos dá a possibilidade de nos tornarmos o outro e experimentarmos, mesmo que pela força da imaginação, os seus sofrimentos. Pesquisando sobre a cultura afro-americana, a escritora se deparou com a história de Margaret Garner, uma escrava do Kentucky que degolara uma de suas filhas quando os policiais e caçadores chegaram à casa em que eles estavam escondidos, em Ohio. Este foi o estopim para a escrita do romance publicado em 1987, cujas circunstâncias e inquietações Morrison ressalta num recente ensaio: 1) a incapacidade da sogra de condenar ou aprovar o assassinato da própria neta; e 2) a serenidade de Margaret 
Garner (MORRISON, 2019, p. 111). Tais questões formaram o coração da preocupação de Morrison, mas, para que ela pudesse desenvolver sua perspectiva, obviamente distinta daquela que caracteriza uma biografia, selecionou personagens, eliminou outros e centrou esforços em tornar Garner, sua sogra e sua filha assassinada o mais próximas possível. A sogra, na narrativa de Morrison, se torna uma pregadora que suporta a escravidão com a força de sua fé, proferindo sermões fora da igreja, na clareira da floresta, enfatizando o valor dos corpos escravizados; e Margaret se tornou Seth, personagem que vislumbra uma centelha de redenção, não sem sentir a profunda ausência de Amada. As palavras da própria autora resumem bem a ideia da literatura como impulsionadora do reconhecimento da alteridade e como geradora de empatia:

A ficção narrativa proporciona uma selva controlada, uma oportunidade de ser e de se tornar o outro. O estrangeiro. Com empatia, clareza e o risco de uma autoinvestigação. Nessa experiência muitas repetida, para mim, autora, a menina Amada, aquela que assombra, é a essência do outro. Clamando eternamente por um beijo (MORRISON, 2019, p. 121).

Desse modo, a experiência da leitura de ficção poderia fornecer um léxico imaginativo extenso a ponto de nos alertar contra a cristalização do nosso vocabulário, para dizê-lo à maneira de Flaubert, numa espécie de Dicionário das ideias feitas, mas também estaria nos capacitaria a construir empatia e compaixão em situações concretas.

\section{Algumas (in)conclusões ou provocações}

O percurso feito suscita pelo menos três provocações. A primeira, de ordem mais geral, diz respeito a uma valorização da ficção e das narrativas da religião. Pelas características já expostas, ambas nos fornecem subsídios para evitar o sequestro de nossas energias psíquicas pelos poderes analíticos. Tanto o mito religioso quanto a ficção literária são formas poéticas de pensar o mundo, ou seja, articulam as dimensões estética, cognitiva e ética. Isto nos leva à próxima questão, de ordem metodológica, por assim dizer.

O desafio de uma compreensão robusta dessas expressões que comungam de certos procedimentos, a literária e a religiosa, e de suas interrelações passa pela conexão dos níveis apontados no parágrafo anterior: do afeto, do conhecimento, e da ação. Reconhecer que, para falar sobre o mundo, as religiões e a literatura discorrem sobre lugares e personagens imaginários, 
pode nos ajudar a evitar duas posturas redutoras. A primeira seria aquela que se aproxima da criação textual a partir da ideia de que ela é apenas um reflexo direto das condições sociais de um dado momento histórico. Estudar a linguagem religiosa e a literatura seria, portanto, aproximá-las das "reais" condições históricas de sua produção. Reconstituir o contexto histórico seria um recurso para atribuir sentido àquilo que dificulta nossa compreensão nos textos em questão. Já a segunda postura considera o texto como intransitivo, como algo que não se relaciona com o mundo. Analisar um texto, por exemplo, se resumiria apenas a prestar atenção para o modo como a linguagem funciona, não dando muita importância para seu impacto no mundo dos leitores. Para uma leitura dos textos religiosos e ficcionais, seria importante uma dedicação aos aspectos relacionados à produção, à forma, mas também aos horizontes de recepção.

A terceira provocação está ligada à especificidade da ficção literária, e recoloca um apontamento feito em nossa argumentação, que poderia ser resumida na pergunta: qual seria a vantagem de se dedicar ao estudo de um mundo imaginário onde tudo é possível e que auto-indica sua própria parcialidade e contingência? O lapidar parágrafo de Frye resume com precisão nossa tese:

Uma das utilidades mais óbvias, penso eu, é o incentivo à tolerância: na imaginação as nossas próprias crenças são simples possibilidades, e ainda enxergamos as possibilidades das crenças alheias. Fanáticos e preconceituosos raramente tentam tirar algum proveito da arte - estão obcecados demais por suas crenças e ações para enxergá-las como talvez simples possibilidades. Também há o outro extremo: o do diletante eternamente entretido por possibilidades e, assim, desprovido de convicções e poder de ação. Mas estes são bem menos comuns que os fanáticos e, no nosso mundo, bem menos perigosos (FRYE, 2017, p. 68).

Destacamos isso não para negar a importância das religiões; se, de um lado, o estudo dos múltiplos universos simbólicos e morais das religiões é indispensável para uma prática efetiva da tolerância, a literatura, por sua vez, seria, também um repositório plural imprescindível que, ao problematizar o nosso vocabulário final por sua ironia intrínseca, permite a sondagem da vida e uma mirada do outro. Por isso, ao ditado: "o homem pensa, Deus ri", o romancista acrescenta: "a arte do romance veio ao mundo como o eco do riso de Deus” (KUNDERA, 2009, p. 146). 
No entanto, cabe perguntar em que medida tais ideias, num momento como o nosso - de pandemia, inflação de narrativas e reconfiguração da tecnologia de produção de textos e experiência de leitura pelas mídias sociais -, continuam pertinentes. É no mínimo curioso, para citar apenas dois exemplos, que $A$ Peste, de Albert Camus, ou o Ensaio sobre a Cegueira, de José Saramago, tenham angariado um número considerável de leitores em 2020 e 2021. Seriam eles capazes de fornecer uma linguagem que: 1) ajuda na percepção dos nossos problemas, isto é, que nomeia nossa peste e nossa cegueira?; 2) contém uma orientação ética distinta da moral prescritiva?; e 3) faz recordar a empatia e a compaixão imprescindíveis a toda comunidade? Obviamente, não seria possível sugerir qualquer explicação definitiva dadas as condições da leitura, ou seja, seu caráter acidental. Dito isso, ensaiamos uma modesta e despretensiosa resposta que depreendemos da experiência narrada por Primo Levi e que se conecta à ideia da importância humanística da literatura. Ao recuperar a memória do campo de concentração, Levi relata o desejo que sentira de compartilhar com outro prisioneiro um trecho da Divina Comédia (LEVI, 1988, p. 114) - trecho este que aludia à urgência de manter em mente o valor irredutível que repousa sobre a vida de todos e todas: "Relembrai vossa origem/ vós não fostes criados para bichos,/ e sim para o valor e para a experiência". O episódio nos faz pensar que, especialmente em situações de crise, os textos literários, por seu estatuto simbólico (e nisso, poderíamos dizer, talvez se assemelhem às narrativas religiosas) são capazes de interrogar uma ordem e colocar a questão de como pensar e viver de outro modo; por outras palavras, são capazes de nos oferecer meios de mantermos acesa a chama de coisas frágeis e precárias, mas que são fundamentais para continuarmos a existir: o valor da liberdade e da alteridade. Ora, em tempos de penumbra, prescindir dos recursos que temos para conservar essa pequena luz trepidando não seria correr o risco de mergulhar de vez na escuridão?

\section{Referências}

ALVES, Rubem. A gestação do futuro. Campinas: Papirus, 1986.

ATER, Robert. A arte da narrativa bíblica. Trad. Vera Maria Pereira. São Paulo: Companhia das Letras, 2007.

Azevedo, Carlito. O Livro das Postagens. Rio de Janeiro: 7 letras, 2016

BARCELLOS, José Carlos. O Drama da Salvação: espaço autobiográfico e experiência cristã em Julien Green. Juiz de Fora: Subiaco, 2008. 
Paulo Nogueira

BORGES, Jorge Luis. Ficções. Trad. Davi Arrigucci Jr. São Paulo: Companhia das Letras, 2007.

BOYD, Brian. The Origin of Stories. Evolution, Cognition and Fiction. Cambridge/ Massachusetts: The Belknap Press of Harvard University Press, 2009.

BOYER, Pascal. Religion Explained. The Evolutionary Origins of Religious Thought. New York: Basic Books, 2001.

BRISSON, Luc. Introdução à filosofia do mito. $2^{\mathrm{a}}$ ed. Trad. José Carlos Baracat Junior. São Paulo: Paulus, 2014.

CERTEAU, Michel de. História e Psicanálise: entre ciência e ficção. Trad. Guilherme J. de Freitas Teixeira. Belo Horizonte: Autêntica Editora, 2016.

CHENU, Marie-Dominique. La théologie comme science au XIII ${ }^{\mathbf{e}}$ siécle. Paris: Vrin, 1957.

COLERIDGE, S. T. Biographia literária ovvero schizzi biograficci della mia vita e opinioni ltterarie. Roma: Editori Reuniti, 1991.

DEACON, Terrence W. The Symbolic Species. The Co-evolution of Language and the Brain. New York/London: W. W. Norton \& Company, 1998.

DESCARTES, René. Discurso do Método. Mem Martins: Publicações Europa-América, 1977.

ECO, Umberto. Seis passeios pelo bosque da ficção. Trad. Hildegard Fest. São Paulo: Companhia das Letras, 1994.

FRYE, Northrop. A imaginação Educada. Trad. Adriel Teixeira, Bruno Geraidine, Cristiano Gomes. Campinas: Vide Editorial, 2017.

ISER, Wolfgang. Ficcionalización: la dimension antropológica de las ficciones literárias. In: Cyber Humanitatis, n.31., inverno, 2004. 20p.

ISER, Wolfgang. O fictício e o imaginário: perspectivas de uma antropologia literária. Trad. Johannes Kretschmer. Rio de Janeiro: EDUERJ, 1996.

KUNDERA, M. A arte do romance. Trad. Teresa Bulhões Carvalho da Fonseca. São Paulo: Companhia das Letras, 2009.

LEVI, Primo. É isto um homem?. Trad. Luigi Del Re. Rio de Janeiro: Rocco, 1988.

LEWIS-WILLIAMS, David. The Mind in the Cave. Consciousness and the Origins of Art. London: Thames \& Hudson, 2009.

LIMA, Luiz Costa. História. Ficção. Literatura. São Paulo: Companhia das Letras, 2011.

MENDONÇA, José Tolentino. Poética da Escrit(ur)a. In: Theologica, 2. ${ }^{a}$ Série, n. 44, 2, 2009, pp. 295-303.

MORRISON, Toni. A origem dos outros: seis ensaios sobre racismo e literatura. Trad. Fernanda Abreu. São Paulo: Companhia das Letras, 2019.

ORDINE, Nucio. Clásicos para la vida: una pequeña biblioteca ideal. Trad. Jordí Bayod. Barcelona: Acantilado, 2017.

OSAKABE, Haquira. Fernando Pessoa: entre almas e estrelas. São Paulo: iluminuras, 2013. 
PAZ, Octavio. O arco e a lira. Trad. Ari Roitman e Paulina Waicht. São Paulo: Cosas Naify, 2012. PESSOA, Fernando. O Marinheiro. Introdução e notas de Marcos Lopes e Ana Maria Ferreira Côrtes. Campinas: Ed. Unicamp, 2020.

PESSOA, Fernando. Obra em prosa. Rio de Janeiro: Aguilar, 2005.

QUINTAIS, Luís. Do canto: uma leitura de Songlines de Bruce Chatwin. Revista de História das Ideias, Faculdade de Letras da Universidade de Coimbra, v. 33, 2012, pp. 47-55.

RORTY, Richard. Contingência, Ironia e Solidariedade. Trad. Vera Ribeiro. São Paulo: Martins Fontes, 2007.

RORTY, Richard. El giro lingüístico. Trad. Gabriel Bello. Barcelona: Paidós, 1990.

RORTY, Richard. Filosofía y futuro. Trad. de Javier Calvo e Angela Ackermann. Barcelona: Gedisa, 2002.

STOCK, Brian. Ethics through Literature: Ascetic and Aesthetic Reading in Western Culture. London: University Press of New England, 2007.

TRILLING, Lionel. A imaginação liberal: ensaios sobre a relação entre literatura e sociedade. Trad. Cecília Prada. São Paulo: É Realizações, 2015.

TÜRCKE, Christoph. Sociedade excitada: filosofia da sensação. Trads. A. Zuin, F. Durão, F. Fontanella e M. Frungillo. Campinas: Unicamp, 2010.

TURNER, Mark. The Literary Mind. The Origins of Thought and Language. Oxford: Oxford University Press, 1996.

WHITE, Hayden. O texto histórico como artefato literário. In: Trópicos do discurso: ensaios sobre a crítica da cultura. Trad. Alípio Correia de Franca Neto. $2^{a}$ ed. São Paulo: EDUSP, 2001, pp. 97-116.

WOOD, James. A coisa mais próxima da vida. Trad. Célia Euvaldo. São Paulo: SESI-SP Editora, 2017.

Submetido em: 26-7-2021

Aceito em: 29-9-2021 